\title{
Genotyping of white spot syndrome virus prevalent in shrimp farms of India
}

\author{
B. Pradeep ${ }^{1}$, Malathi Shekar ${ }^{1}$, Nicholas Gudkovs ${ }^{2}$, Iddya Karunasagar ${ }^{1}$, \\ Indrani Karunasagar ${ }^{1, *}$
}

${ }^{1}$ Department of Fishery Microbiology, Karnataka Veterinary, Animal and Fisheries Sciences University, College of Fisheries, Mangalore 575 002, India

${ }^{2}$ CSIRO Australian Animal Health Laboratory, 5 Portarlington Road, East Geelong, Victoria 3220, Australia

\begin{abstract}
DNA extracts from white spot syndrome virus (WSSV) that had infected post-larvae and juveniles of cultured shrimp, wild shrimp and crabs, which had been collected from different hatcheries and farms located along both the east and west coasts of India, revealed considerable variation in several previously identified WSSV DNA repeat regions. These include the 54 bp repeat in ORF 94, the 69 bp repeat in ORF 125 and the compound 45 and 57 bp repeat region in ORF 75. In ORF 94, 13 genotypes were observed with the number of repeats ranging from 2 to 16 units. While 7 repeat units were commonly observed $(11.3 \%)$, no samples with 11 or 15 repeat units were found. In ORF 125, 11 types were found, with repeats ranging from 2 to 14 units. The most prevalent genotype displayed 4 repeat units $(47.1 \%)$; no samples with 6 or 13 repeats were observed. The compound repeat region of ORF 75 displayed 6 different patterns of repeats. Samples with the same repeat pattern in one ORF did not always show identical repeat patterns in one or both of the other repeat regions. These data suggest that combined analysis of all 3 variable loci could be used to differentiate and characterize specific WSSV strains. For general epidemiological studies, the best marker with maximum variation is ORF 94, followed by ORF 125 and ORF 75. The 3 repeat regions above were used to compare WSSV genotypes from disease outbreaks on 3 sets of farms from different locations in the state of Andhra Pradesh. The genotypes within each farm set were almost identical, but differed between farm sets, suggesting that WSSV transmission occurred directly through virus carriers or water exchange between adjacent farms at each location. These findings show that genotyping can be a useful epidemiological tool for tracing the movement of WSSV within infected populations.
\end{abstract}

KEY WORDS: WSSV · Genotyping · Variable number tandem repeats $\cdot$ Minisatellites $\cdot$ Epidemiology

Resale or republication not permitted without written consent of the publisher

\section{INTRODUCTION}

White spot syndrome virus (WSSV) is the most important viral pathogen of farmed shrimp, and often leads to mass mortalities and severe economic loss to farmers. The virus infects a wide range of aquatic crustaceans, including marine and brackish water penaeids, crabs, freshwater prawns and crayfish (Lo et al. 1996, Wang et al. 1998, Hossain et al. 2001). Electron microscopic studies have shown that the virus has a rod shaped nucleocapsid with a cross-hatched appearance, surrounded by a trilaminar envelope, and has a unique tail-like appendage at one end (Wongteerasupaya et al.
1995, Durand et al. 1997, Nadala et al. 1998). WSSV is the sole member of the family Nimaviridae, genus Whispovirus (Mayo 2002, Vlak et al. 2004). It is a double-stranded DNA virus with a large circular genome of approximately $300 \mathrm{~kb}$ and is one of the largest genomes of animal viruses yet described (van Hulten et al. 2001, Yang et al. 2001). Since its discovery in Fujian, China, during 1991 to 1992, the virus has spread rapidly to all the major shrimp farming countries of the world (Flegel 1997) including India, where severe mortalities of cultured shrimp due to this virus have been reported along the east coast since 1994 to 1995 (Karunasagar et al. 1997). 
The various geographical isolates of WSSV identified are very similar in morphology and protein profile (Dieu et al. 2004). The restriction fragment length polymorphism (RFLP) patterns of isolates show only limited differences, suggesting a high degree of genomic stability (Nadala \& Loh 1998, Lo et al. 1999, Wang et al. 2000a,b, Dieu et al. 2004, Marks et al. 2004). The 3 complete genome sequences of WSSV isolated from Taiwan (WSSV-TW, Tsai et al. 2000, Acc. No. AF440570), China (WSSV-CN, Yang et al. 2001, Acc. No. AF332093) and Thailand (WSSV-TH, van Hulten et al. 2001, Acc. No. AF369029) have an overall identity of $99.32 \%$. The 5 major differences that exist among the isolates include a large deletion region of $\sim 13.2 \mathrm{~kb}$ in WSSV-TH and $\sim 1.2 \mathrm{~kb}$ in WSSV$\mathrm{CN}$ genome relative to WSSV-TW, a variable region prone to recombination, a transposase sequence present only in WSSV-TW, variation in the number of repeat units within homologous (hrs) and direct repeats and single nucleotide mutations involving deletion, insertion or single nucleotide polymorphisms (SNPs) (Dieu et al. 2004, Marks et al. 2004, Shekar et al. 2005). The variations associated with ORF 23/24 and ORF $14 / 15$ within the WSSV-TH are prone to deletion and recombination events, respectively, and are reported to be useful in identifying evolutionary changes in WSSV (Marks et al. 2005). A number of variable microsatellites, minisatellites and megasatellites are reported as markers for WSSV, of which the variable number tandem repeats (VNTRs) associated with the 3 minisatellites, ORF 94, ORF 75 and ORF 125, have been suggested as potential markers for epidemiological studies (Dieu et al. 2004, Marks et al. 2004, Shekar et al. 2005). A bioinformatics-based study of VNTRs by Shekar et al. (2005) has shown that the minisatellite in coding regions of ORF 94, ORF 125 and ORF 75 consists of a 54 bp uniform repeat, a $69 \mathrm{bp}$ uniform repeat and a compound repeat of 45 and $57 \mathrm{bp}$, respectively. Among the 3 minisatellites, ORF 94 located between the ribonucleotide reductase genes ( $r r 1)$ and ( $r r 2)$ has been used for genotyping WSSV (van Hulten et al. 2000, Wongteerasupaya et al. 2003, Dieu et al. 2004, Hoa et al. 2005, Musthaq et al. 2006). Dieu et al. (2004) used all 5 differences identified in the 3 completely sequenced WSSV isolates for genotyping isolates from Vietnam. The present study is the first attempt to compare the utility of these 3 minisatellites as epidemiological markers for genotyping WSSV from crustaceans in India.

\section{MATERIALS AND METHODS}

Sampling. A total of 513 samples, including cultured shrimp at various stages of growth and other suspected WSSV carriers like crabs and wild shrimp, were collected during the study period (February 2005 to October 2006) from the east (Andhra Pradesh and Tamil Nadu) and west (Kerala and Karnataka) coasts of India (Fig. 1, see Table 3). The samples included post-larvae (PL) supplied by different hatcheries, juvenile and adult shrimp collected from ponds at about 45 and $90 \mathrm{~d}$ of culture, and potential carriers like wild shrimp and crabs collected from different culture ponds where WSSV outbreaks were in progress. Samples were also collected from natural ecosystems like creeks and canals. The collected samples were preserved in $95 \%$ ethanol and transported to the laboratory for further analysis.

DNA extraction. Approximately $50 \mathrm{mg}$ of pleopods from each adult shrimp, periopods from juveniles (25 to 30 PL), crab legs and the telson region of wild shrimp were used for DNA extraction. Ethanol was removed from tissues using blotting paper. The dried tissues were then transferred to $1.5 \mathrm{ml}$ microcentrifuge tubes and homogenized in $800 \mu$ ldigestion buffer $(10 \mathrm{mM}$ Tris-HCl [pH 8.0], 0.1 M EDTA [pH 8.0], 0.5\% Triton $\mathrm{X}-100,6 \mathrm{M}$ guanidine hydrochloride, $0.1 \mathrm{M}$ sodium acetate). The homogenate was incubated at ambient temperature $\left(28 \pm 1^{\circ} \mathrm{C}\right)$ for $10 \mathrm{~min}$ followed by centrifugation at $10000 \times g$ for $10 \mathrm{~min}$. The supernatant was transferred to a fresh tube containing an equal volume of phenol:chloroform:isoamyl alcohol (25:24:1), vortex mixed and centrifuged at $5000 \times g$ for $5 \mathrm{~min}$. The aqueous phase containing DNA was transferred to a fresh

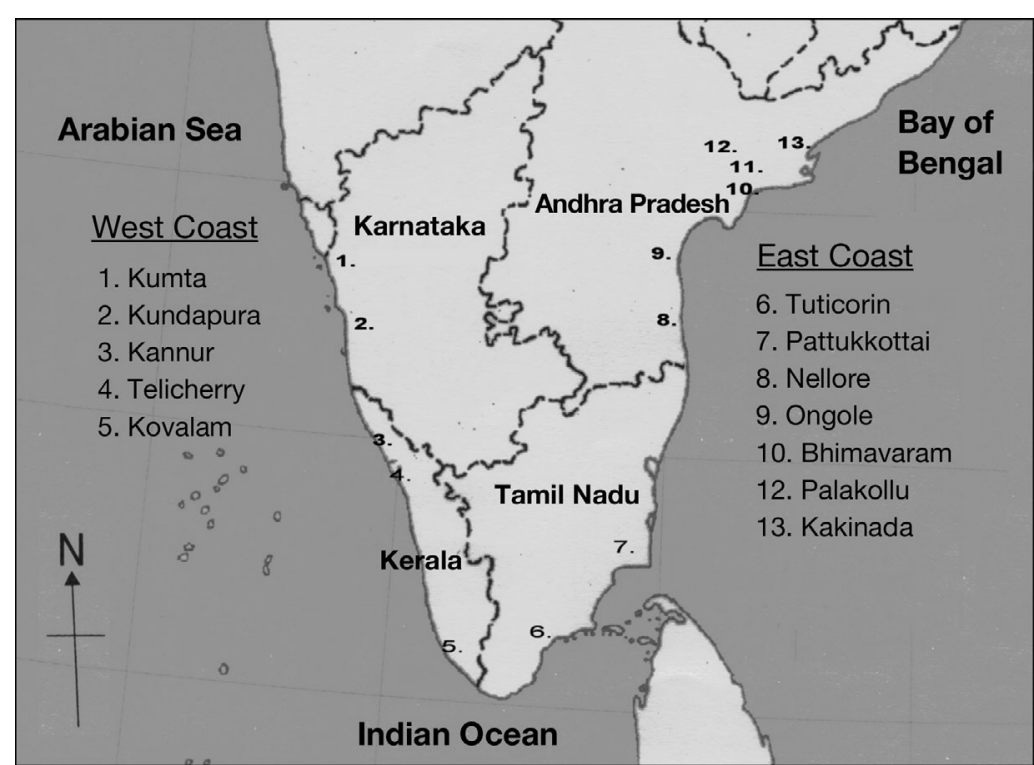

Fig. 1. Southern India showing sample collection sites on or near east and west coasts 
tube and precipitated by adding 2 volumes of absolute ethanol followed by centrifugation at $14000 \times g$ for $10 \mathrm{~min}$. The pellet was washed with $1 \mathrm{ml}$ of $95 \%$ ethanol and then dried. The pellet was washed again with $70 \%$ ethanol, dried and finally dissolved in $100 \mu \mathrm{l}$ of $1 \times$ Tris-ethylenediaminetetraacetic acid (TE) buffer ( $\mathrm{pH}$ 8.0). The extracted DNA was stored at $-20^{\circ} \mathrm{C}$ until further use.

Diagnostic PCR for WSSV. Samples containing WSSV DNA were identified with a 2-step nested-PCR using primers IK-1/2 and IK-3/4 (Table 1). The reaction mixture was composed of $10 \times$ buffer $(100 \mathrm{mM} \mathrm{HCl} \mathrm{[pH} \mathrm{8.3],}$ $20 \mathrm{mM} \mathrm{MgCl}_{2}, 500 \mathrm{mM} \mathrm{KCl}, 1 \%$ gelatin), $200 \mu \mathrm{M}$ of each deoxyribonucleotide triphosphate (dATP, dTTP, dGTP and dCTP) and 3 units of Taq DNA polymerase. PCR was performed using a DNA Engine DYAD (MJ Research) thermal cycler. Cycling conditions and expected product size are summarized in Table 2.

Analysis of variable number tandem repeats (VNTRs). For all WSSV positive samples, PCR was carried out for 3 minisatellite regions, one containing a $54 \mathrm{bp}$ repeat (ORF 94), one a 69 bp repeat (ORF 125) and one a compound repeat of 45 and $57 \mathrm{bp}$ (ORF 75). Specific primers (Table 1) were used with initial denaturation for $5 \mathrm{~min}$ followed by cycling conditions as specified in Table 2. The primers for ORF 125 and ORF 75 were designed using PRIMER3 online software (http://frodo.wi.mit.edu/cgi-bin/primer3/primer3_www. cgi), while the previously described primers for ORF 94 (Wongteerasupaya et al. 2003) and ORF 75 (Dieu et al. 2004) were used. Amplification products were analysed by electrophoresis in $1.5 \%$ agarose gel containing ethidium bromide and visualized using a gel documentation system (Herolab RH-2.1). The amplicon sizes were determined using Kodak Digital Science 1D (KSD1D 2.0) software. The number of repeat units (RUs) in the amplicons obtained were calculated as [amplicon size $-(171+12)] / 54$ and (amplicon size + 35 - 92)/69 for the $54 \mathrm{bp}$ and $69 \mathrm{bp}$ repeats, respectively. Here, the numbers 171 and 92 denote the total number of bases adjacent to the repeat unit region amplified by the forward and reverse primers. Twelve bases were subtracted and 35 bases added to the amplicon size obtained for the $54 \mathrm{bp}$ and $69 \mathrm{bp}$ repeats,

Table 1. Primers used for PCR analysis in WSSV genotyping

\begin{tabular}{|c|c|c|}
\hline Primer specific for & Primer & Sequence $\left(5^{\prime}-3^{\prime}\right)$ \\
\hline \multirow{2}{*}{ WSSV 1st step } & IK 1 & TGGCATGACAACGGCAGGAG \\
\hline & IK 2 & GGCTTCTGAGATGAGGACGG \\
\hline \multirow[t]{2}{*}{ WSSV 2nd step } & IK 3 & TGTCATCGCCAGCACGTGTGC \\
\hline & IK 4 & AGAGGTCGTCAGAGCCTAGTC \\
\hline \multirow[t]{2}{*}{ ORF 94 (WSSV 54 bp repeat region) } & WSR F & TCTACTCGAGGAGGTGACGAC \\
\hline & WSR R & AGCAGGTGTGTACACATTTCATG \\
\hline \multirow[t]{2}{*}{ ORF 125 (WSSV 69 bp repeat region) } & ORF $125 \mathrm{~F}$ & TGGAAACAGAGTGAGGGTCA \\
\hline & ORF $125 \mathrm{R}$ & CATGTCGACTATACGTTGAATCC \\
\hline \multirow[t]{2}{*}{ ORF 75 (WSSV compound repeat region) } & ORF $75 \mathrm{~F}$ & GCCAGATTTCTTCСССТАСC \\
\hline & ORF $75 \mathrm{R}$ & CTCCATGTAGAGGCAAAGCA \\
\hline \multirow[t]{2}{*}{ ORF 75 (WSSV compound repeat region) } & ORF 75 FLANK (F) & GAAGCAGTATCTCTAACAC \\
\hline & ORF 75 FLANK (R) & CAACAGGTGCGTAAAAGAAG \\
\hline \multirow[t]{2}{*}{ Strataclone kit primers } & T3 & AATTAACCCTCACTAAAGGGAA \\
\hline & T 7 & GTAATACGACTCACTATAGG \\
\hline
\end{tabular}

Table 2. PCR cycling conditions

\begin{tabular}{|c|c|c|c|c|c|}
\hline Primers & Denaturation & $\begin{array}{c}\text { Cycling conditions } \\
\text { Annealing }\end{array}$ & Extension & $\begin{array}{l}\text { No. of } \\
\text { cycles }\end{array}$ & $\begin{array}{l}\text { Product size } \\
\text { (bp) }\end{array}$ \\
\hline $\begin{array}{l}\mathrm{IK}-1 / 2 \\
\mathrm{IK}-3 / 4\end{array}$ & $95^{\circ} \mathrm{C}$ for $30 \mathrm{~s}$ & $55^{\circ} \mathrm{C}$ for $30 \mathrm{~s}$ & $72^{\circ} \mathrm{C}$ for $30 \mathrm{~s}$ & 30 & $\begin{array}{l}486 \\
310\end{array}$ \\
\hline $\begin{array}{l}\text { WSR F/R } \\
\text { (ORF 94) }\end{array}$ & $95^{\circ} \mathrm{C}$ for $45 \mathrm{~s}$ & $55^{\circ} \mathrm{C}$ for $45 \mathrm{~s}$ & $72^{\circ} \mathrm{C}$ for $45 \mathrm{~s}$ & 35 & Variable \\
\hline ORF $125 \mathrm{~F} / \mathrm{R}$ & $95^{\circ} \mathrm{C}$ for $30 \mathrm{~s}$ & $60^{\circ} \mathrm{C}$ for $30 \mathrm{~s}$ & $72^{\circ} \mathrm{C}$ for $30 \mathrm{~s}$ & 35 & Variable \\
\hline $\begin{array}{l}\text { ORF } 75 \text { F/R } \\
\text { ORF } 75\end{array}$ & $95^{\circ} \mathrm{C}$ for $45 \mathrm{~s}$ & $52^{\circ} \mathrm{C}$ for $45 \mathrm{~s}$ & $72^{\circ} \mathrm{C}$ for $45 \mathrm{~s}$ & 35 & Variable \\
\hline FLANK F/R & $95^{\circ} \mathrm{C}$ for $80 \mathrm{~s}$ & $49^{\circ} \mathrm{C}$ for $80 \mathrm{~s}$ & $72^{\circ} \mathrm{C}$ for $80 \mathrm{~s}$ & 30 & Variable \\
\hline T3/T7 & $95^{\circ} \mathrm{C}$ for $60 \mathrm{~s}$ & $55^{\circ} \mathrm{C}$ for $60 \mathrm{~s}$ & $72^{\circ} \mathrm{C}$ for $60 \mathrm{~s}$ & 30 & Variable \\
\hline
\end{tabular}


respectively, in order to have the RUs expressed as a whole number. In the case of the compound repeat, the amplicon size recorded was that which was obtained.

Cloning and sequencing of PCR products. The PCR products were purified using a PCR purification kit (Qiagen). Purified products were subsequently cloned into pSCA cloning vector (Strataclone) and the positive clones were screened by PCR using the corresponding minisatellite primers. The plasmids from the clones were extracted using a Fast Plasmid Mini kit (Eppendorf) and sequenced using T3 and T7 primers.

Sequence analysis. The sequences obtained were analyzed for the presence of tandem repeats using Tandem Repeats Finder (TRF) program (Benson 1999). Comparative analysis of repeats was performed using BLAST and ClustalW programs. The repeats were also compared with the 3 complete WSSV genomes at GenBank.

Virus purification and infectivity studies. Isolation and purification of WSSV from the muscle tissue of infected shrimp were performed as previously described by Xie et al. (2005). The purified virus was diluted with $0.9 \% \mathrm{NaCl}(1: 1)$ and $50 \mu \mathrm{l}$ injected intramuscularly into shrimp weighing approximately $10 \mathrm{~g}$. After $3 d$, DNA was extracted from the inoculated shrimp and subjected to PCR analysis for WSSV and variable loci as described above.

Epidemiological studies. Outbreaks of WSSV disease in 2006 in Andhra Pradesh were considered to be among the most severe recorded, as they caused mass mortalities in many shrimp farming areas that had previously been uninfected. To identify the difference in repeat patterns for WSSV from farms within a location we selected 3 sites in Andhra Pradesh, viz. Bhimavaram, Kakinada and Palakollu (Fig. 1). All these farms were stocked initially with WSSV negative PL.

\section{RESULTS}

\section{PCR for WSSV}

Of the 513 samples analyzed (Table 3), 106 samples $(20.7 \%)$ were positive for WSSV. Further, the percentage prevalence in different samples was 22 of 268 $(8.2 \%)$ in PL, 6 of $21(28.6 \%)$ in juveniles, 28 of 103 $(27.2 \%)$ in planned harvest samples, 45 of $62(72.6 \%)$ in samples from disease outbreak, 2 of $22(9.1 \%)$ in wild shrimp and 3 of $37(8.1 \%)$ in crabs (Table 3 ).

\section{PCR for the 54 bp RU in ORF 94}

Thirteen different repeat types ranging from 2 to 16 RUs were found in ORF 94. The most frequent re- peat type had 7 RUs (11.3\%) while types with 11 or 15 RUs were not observed (Table 4). Samples with 7 RUs were found in both outbreak $(4.7 \%$ ) and non-outbreak ponds, including those with PL and planned harvest shrimps (6.6\%). The 7 RU type was the dominant genotype found in samples collected during 2005, while most samples collected from outbreaks ponds during 2006 had 2 RUs (26.9\%). This also included samples collected from farms that were infected for the first time. Shrimps with 2 RUs were also recorded from 2 non-outbreak ponds of 106 (1.9\%), of which one was a PL sample. In general, RU types 2 to 8 were dominant in 30 of 106 outbreak ponds $(28.3 \%)$ when compared with 17 of $106(16.0 \%)$ in non-outbreak ponds, whereas higher RU 9 to 16 accounted for only 4 of 106 (3.7\%) in outbreak ponds and 14 of $106(13.7 \%)$ in non-outbreak ponds. In 2 samples, there were 2 bands of different amplicon sizes, indicating a dual infection by 2 different genotypes of WSSV (Fig. 2, Lane 7). WSSV positive carriers like crabs and wild shrimp did not produce any amplification for this PCR. Sequencing of the PCR product from the 2-RU type revealed a single nucleotide polymorphism (SNP) at the 48th base of the 2 nd repeat unit ( $\mathrm{T}$ instead of $\mathrm{G}$ ). Similarly, sequencing the product having the 5-RU type showed complete nucleotide identity, except for the 4 th repeat unit that had a $\mathrm{G}$ instead of $\mathrm{A}$ at the 7 th and 44 th positions.

\section{PCR for the 69 bp RU in ORF 125}

Thirteen repeat types ranging from 2 to 14 RUs were found for the $69 \mathrm{bp}$ RU. The most common type had 4 RUs $(47.2 \%)$. No samples with 6 or 13 RUs were found (Table 4, Fig.3). In 3 samples, 2 amplicons of different size were seen. This is a possible indication of a

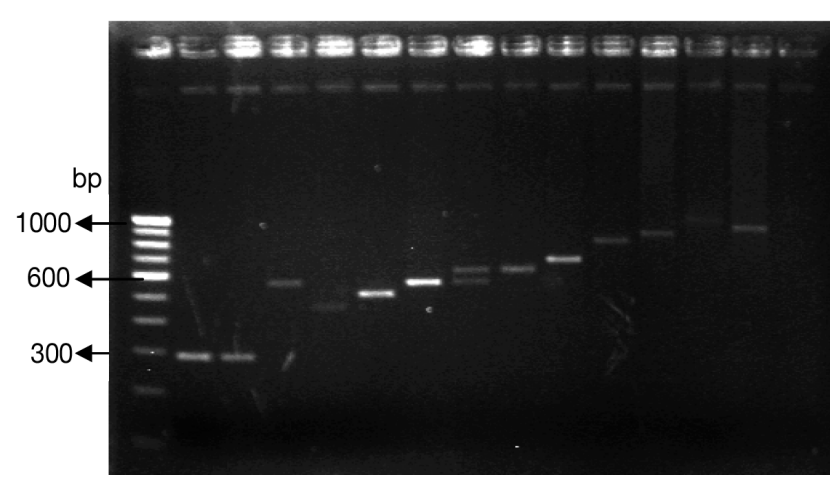

Fig. 2. Agarose gel showing PCR amplification product for ORF 94, 54 bp repeats (Lanes 1 to 14 represent shrimp samples from different regions). Lane 7 shows infection by 2 different WSSV strains; Lane 14 is WSSV sample showing no amplification product; Lane $\mathrm{M}$ is $100 \mathrm{bp}$ molecular weight marker 
Table 3. Prevalence of WSSV in different samples from east and west coasts of India. Location of farms and hatcheries on the east coast: Tamil Nadu (Tuticorin, Pattukkottai), Andhra Pradesh (Nellore, Ongole, Bapatla, Bhimavaram, Palakollu, Kakinada); location of farms and hatcheries on the west coast: Karnataka (Kundapura, Kumta), Kerala (Kannur, Kovalam, Telicherry)

\begin{tabular}{|c|c|c|c|c|c|}
\hline $\begin{array}{l}\text { Sample type } \\
\text { and species }\end{array}$ & $\begin{array}{l}\text { Geographical } \\
\text { location }\end{array}$ & Coastal state & $\begin{array}{l}\text { Number of } \\
\text { samples }\end{array}$ & $\begin{array}{c}\text { Number of } \\
\text { samples positive } \\
\text { for WSSV }\end{array}$ & $\begin{array}{c}\% \text { prevalence } \\
\text { of WSSV }\end{array}$ \\
\hline $\begin{array}{l}\text { Post-larvae } \\
\text { Penaeus monodon }\end{array}$ & $\begin{array}{l}\text { East coast } \\
\text { West coast }\end{array}$ & $\begin{array}{l}\text { Tamil Nadu } \\
\text { Andhra Pradesh } \\
\text { Karnataka } \\
\text { Kerala } \\
\text { Total }\end{array}$ & $\begin{array}{c}22 \\
86 \\
96 \\
64 \\
\mathbf{2 6 8}\end{array}$ & $\begin{array}{c}3 \\
7 \\
8 \\
4 \\
22\end{array}$ & $\begin{array}{c}13.6 \\
8 . \\
8.3 \\
6.3 \\
\mathbf{8 . 2}\end{array}$ \\
\hline $\begin{array}{l}\text { Juveniles } \\
\text { Penaeus monodon }\end{array}$ & $\begin{array}{l}\text { East coast } \\
\text { West coast }\end{array}$ & $\begin{array}{l}\text { Tamil Nadu } \\
\text { Andhra Pradesh } \\
\text { Karnataka } \\
\text { Kerala } \\
\text { Total }\end{array}$ & $\begin{array}{c}8 \\
9 \\
3 \\
1 \\
\mathbf{2 1}\end{array}$ & $\begin{array}{l}2 \\
3 \\
1 \\
0 \\
6\end{array}$ & $\begin{array}{c}25.0 \\
33.3 \\
33.3 \\
- \\
\mathbf{2 8 . 6}\end{array}$ \\
\hline $\begin{array}{l}\text { Planned harvest } \\
\text { Penaeus monodon }\end{array}$ & $\begin{array}{l}\text { East coast } \\
\text { West coast }\end{array}$ & $\begin{array}{l}\text { Tamil Nadu } \\
\text { Andhra Pradesh } \\
\text { Karnataka } \\
\text { Kerala } \\
\text { Total }\end{array}$ & $\begin{array}{c}15 \\
68 \\
8 \\
12 \\
103\end{array}$ & $\begin{array}{c}5 \\
16 \\
2 \\
5 \\
\mathbf{2 8}\end{array}$ & $\begin{array}{l}33.3 \\
23.5 \\
25.0 \\
41.7 \\
\mathbf{2 7 . 2}\end{array}$ \\
\hline $\begin{array}{l}\text { Disease outbreak } \\
\text { Penaeus monodon }\end{array}$ & $\begin{array}{l}\text { East coast } \\
\text { West coast }\end{array}$ & $\begin{array}{l}\text { Tamil Nadu } \\
\text { Andhra Pradesh } \\
\text { Karnataka } \\
\text { Kerala } \\
\text { Total }\end{array}$ & $\begin{array}{c}13 \\
34 \\
10 \\
5 \\
62\end{array}$ & $\begin{array}{c}8 \\
26 \\
7 \\
4 \\
\mathbf{4 5}\end{array}$ & $\begin{array}{l}61.5 \\
76.5 \\
70.0 \\
80.0 \\
\mathbf{7 2 . 6}\end{array}$ \\
\hline $\begin{array}{l}\text { Wild shrimp } \\
\text { Acetes sp. }\end{array}$ & $\begin{array}{l}\text { East coast } \\
\text { West coast }\end{array}$ & $\begin{array}{l}\text { Tamil Nadu } \\
\text { Andhra Pradesh } \\
\text { Karnataka } \\
\text { Total }\end{array}$ & $\begin{array}{c}5 \\
11 \\
6 \\
22\end{array}$ & $\begin{array}{l}0 \\
1 \\
1 \\
2\end{array}$ & $\begin{array}{c}- \\
9.1 \\
16.7 \\
\mathbf{9 . 1}\end{array}$ \\
\hline $\begin{array}{l}\text { Crabs } \\
\text { Scylla serrata }\end{array}$ & $\begin{array}{l}\text { East coast } \\
\text { West coast }\end{array}$ & $\begin{array}{l}\text { Tamil Nadu } \\
\text { Andhra Pradesh } \\
\text { Karnataka } \\
\text { Kerala } \\
\text { Total }\end{array}$ & $\begin{array}{c}13 \\
18 \\
4 \\
2 \\
37\end{array}$ & $\begin{array}{l}1 \\
2 \\
0 \\
0 \\
3\end{array}$ & $\begin{array}{c}7.7 \\
11.1 \\
- \\
- \\
\mathbf{8 . 1}\end{array}$ \\
\hline
\end{tabular}

Table 4. Repeat units (RU) present in the region encoding ORF 94, ORF 125 and ORF 75. DF = detection failure

\begin{tabular}{|c|c|c|c|c|c|c|c|c|c|}
\hline \multirow[b]{2}{*}{$\begin{array}{l}\text { No. } \\
\text { of RU }\end{array}$} & \multicolumn{3}{|c|}{ ORF 94 (54 bp RU) } & \multicolumn{3}{|c|}{ ORF 125 (69 bp RU) } & \multicolumn{3}{|c|}{ ORF 75 (45 and 57 bp RUs) } \\
\hline & $\begin{array}{l}\text { Amplicon } \\
\text { size (bp) }\end{array}$ & $\begin{array}{c}\text { No. of } \\
\text { samples }\end{array}$ & $\begin{array}{c}\text { Frequency } \\
(\%)\end{array}$ & $\begin{array}{l}\text { Amplicon } \\
\text { size (bp) }\end{array}$ & $\begin{array}{l}\text { No. of } \\
\text { samples }\end{array}$ & $\begin{array}{c}\text { Frequency } \\
\qquad(\%)\end{array}$ & $\begin{array}{l}\text { Amplicon } \\
\text { size (bp) }\end{array}$ & $\begin{array}{l}\text { No. of } \\
\text { samples }\end{array}$ & $\begin{array}{c}\text { Frequency } \\
(\%)\end{array}$ \\
\hline 2 & 291 & 9 & 8.5 & 195 & 3 & 2.8 & 320 & 1 & 0.9 \\
\hline 3 & 345 & 7 & 6.6 & 264 & 2 & 1.9 & 427 & 1 & 0.9 \\
\hline 4 & 399 & 3 & 2.8 & 333 & 50 & 47.2 & 525 & 25 & 23.6 \\
\hline 5 & 453 & 1 & 0.9 & 402 & 16 & 15.1 & 540 & 15 & 14.2 \\
\hline 6 & 507 & 6 & 5.7 & 471 & 0 & 0 & 610 & 5 & 4.7 \\
\hline 7 & 561 & 12 & 11.3 & 540 & 5 & 4.7 & 778 & 3 & 2.8 \\
\hline 8 & 615 & 9 & 8.5 & 609 & 17 & 16.0 & DF & 56 & 52.8 \\
\hline 9 & 669 & 3 & 2.8 & 678 & 1 & 0.9 & & & \\
\hline 10 & 723 & 7 & 6.6 & 747 & 2 & 1.9 & & & \\
\hline 11 & 777 & 0 & 0 & 816 & 1 & 0.9 & & & \\
\hline 12 & 831 & 3 & 2.8 & 885 & 1 & 0.9 & & & \\
\hline 13 & 885 & 1 & 0.9 & 954 & 0 & 0 & & & \\
\hline 14 & 939 & 1 & 0.9 & 1023 & 1 & 0.9 & & & \\
\hline 15 & 993 & 0 & 0 & DF & 7 & 6.6 & & & \\
\hline \multirow[t]{2}{*}{16} & 1047 & 3 & 2.8 & & & & & & \\
\hline & $\mathrm{DF}$ & 41 & 38.7 & & & & & & \\
\hline
\end{tabular}




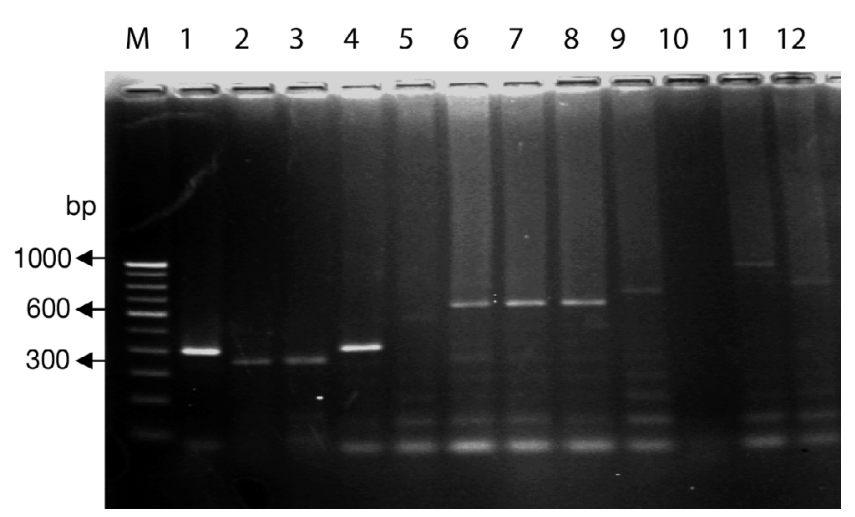

Fig. 3. Agarose gel showing PCR amplification product for ORF 125, 69 bp repeats (Lanes 1 to 12 represent shrimp samples from different regions). Lane 10 is WSSV sample showing no amplification product; Lane $\mathrm{M}$ is $100 \mathrm{bp}$ molecular weight marker

dual infection by 2 different WSSV genotypes. Sequencing of 4-RU amplicons revealed SNPs in the first repeat unit at positions 29, 37, 40, 43, 55 and 56, and in the 4 th repeat unit at positions 50, 53 and 61.

\section{PCR for the compound RU in ORF 75}

Two different primer sets were used. ORF 75 F/R primers failed to yield any detectable product for most of the samples. As a result, the primers ORF 75 FLANK F/R (Dieu et al. 2004) were used for analysis. Of the 106 samples tested, $47.2 \%$ gave a visible product, with the majority yielding an amplicon of $525 \mathrm{bp}$ (Table 4). Cloning and sequencing of a $758 \mathrm{bp}$ fragment obtained from ORF $75 \mathrm{~F} / \mathrm{R}$ primers revealed a compound repeat pattern of $45 \times 2,57,45 \times 5,57,45,57,45 \times 2$ (Fig. 4) that differed from $45 \times 2,57,45 \times 5,57,45 \times 3,57,45 \times$ 2 for the ORF 75 region of WSSV-TH. Sequencing of a smaller fragment of $412 \mathrm{bp}$ revealed a repeat pattern of $45 \times 3,57$ and $45 \times 2$ only.

\section{Epidemiological analysis}

We observed that the WSSV repeat patterns for the 3 ORFs were identical or nearly identical for samples from multiple farms within each of our 3 geographical locations, but that they differed between locations (Table 5). For example, samples collected from individual farms at Palakollu showed identical repeat patterns

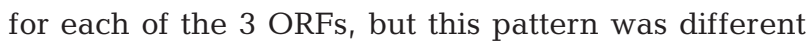
from that observed at the other 2 locations. A minor variation in the repeat pattern was observed in one sample from Bhimavaram. This sample originated from a farm more remote from the others in the group. Apart from having 7 RUs instead of 8 RUs in ORF 94, the patterns observed were identical to those of the other samples from the same location. In ORF 125, crab samples obtained from some ponds showed patterns of repeats similar to those from shrimp samples collected at the same location.

\section{Infectivity studies}

Shrimp infectivity studies, using inoculum prepared from WSSV PCR positive shrimp samples, resulted in development of white spot disease $3 \mathrm{~d}$ post-inoculation. WSSV genotyping of samples from the challenged shrimp revealed identical RU patterns to the inoculums for the 3 ORFs examined.

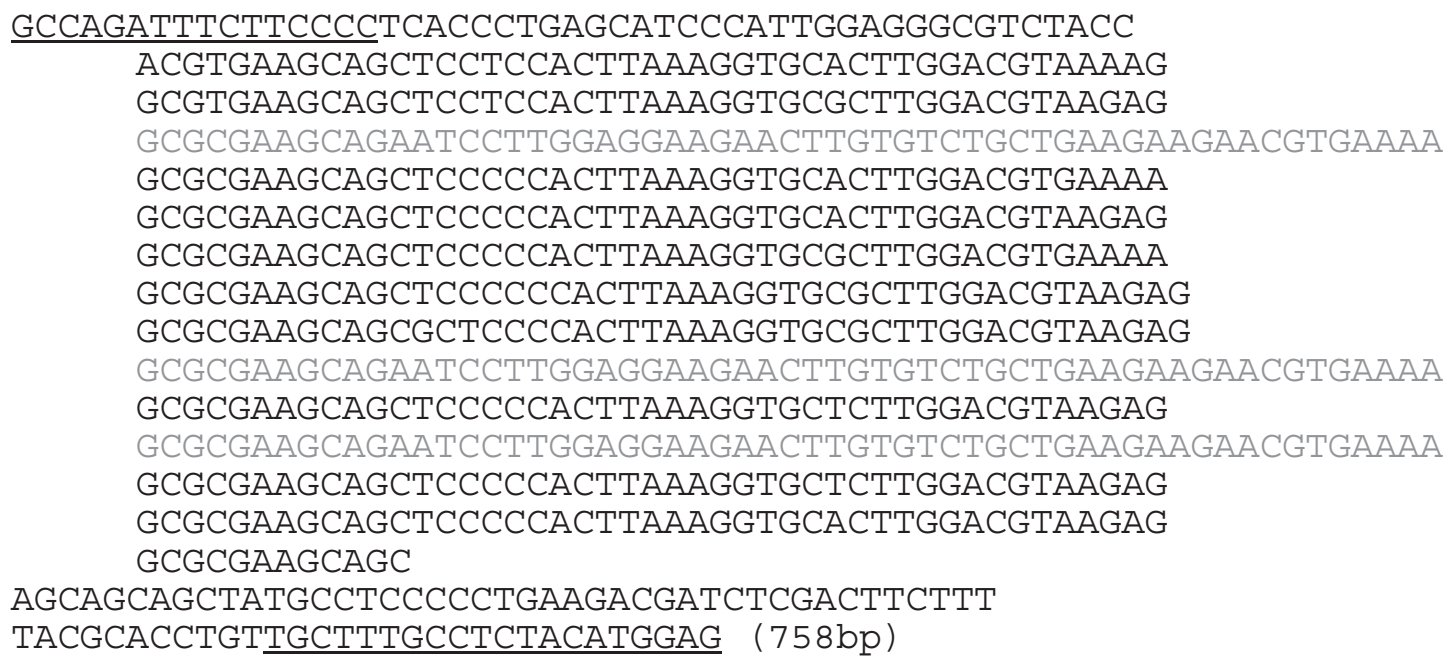

Fig. 4. Representative ORF 75 region showing the compound repeat sequence of 45 and 57 bp repeat units. Letters in grey indicate 57 bp repeat. Primer binding sites are underlined 
Table 5. Repeat unit patterns in WSSV samples from farms of different geographical locations

\begin{tabular}{|lcccc|}
\hline Location & $\begin{array}{c}\text { Farm } \\
\text { no. }\end{array}$ & $\begin{array}{c}54 \mathrm{bp} \\
\text { repeat } \\
\text { unit }\end{array}$ & $\begin{array}{c}69 \mathrm{bp} \\
\text { repeat } \\
\text { unit }\end{array}$ & $\begin{array}{c}45 \text { and } 57 \mathrm{bp} \\
\text { repeat units } \\
\text { (amplicon size) }\end{array}$ \\
\hline Palakollu & 1 & 2 & 5 & $540 \mathrm{bp}$ \\
& 2 & 2 & 5 & $540 \mathrm{bp}$ \\
& 3 & 2 & 5 & $540 \mathrm{bp}$ \\
Kakinada & 4 & 2 & 5 & $540 \mathrm{bp}$ \\
& 2 & 6 & 5 & $540 \mathrm{bp}$ \\
& 3 & 6 & 5 & $540 \mathrm{bp}$ \\
& 4 & 6 & 5 & $540 \mathrm{bp}$ \\
& 1 & 7 & 8 & $540 \mathrm{bp}$ \\
& 2 & 7 & 8 & $540 \mathrm{bp}$ \\
& 3 & 7 & 8 & $540 \mathrm{bp}$ \\
& 4 & 8 & 8 & $540 \mathrm{bp}$ \\
\hline
\end{tabular}

\section{DISCUSSION}

Genotyping of WSSV is mainly based on the variable number tandem repeats (VNTRs) associated with the DNA minisatellites in the WSSV genome and the SNPs associated within the repeats. Of the 3 minisatellites in the WSSV genome, ORF 94 with a 54 bp repeat region has most commonly been used for previous attempts at genotyping (van Hulten et al. 2000, Wongteerasupaya et al. 2003, Dieu et al. 2004, Hoa et al. 2005, Musthaq et al. 2006, Waikhom et al. 2006). In this study, 3 minisatellite regions from ORF 94, 125 and 75 were used for genotyping WSSV from India.

Wongteerasupaya et al. (2003) first demonstrated a practical method of differentiating WSSV genotypes based on the VNTRs associated with ORF 94. These shrimp originated from WSSV outbreak ponds in Thailand in 2000 and 2002. The most commonly observed genotype in that study had 8 repeats $(32 \%)$ and genotypes with 6 to 9 repeats accounted for $70 \%$ of all outbreak samples, with 6 being the lowest number of repeats observed. These authors noted a SNP at the 36th position (substitution of T or G). Hoa et al. (2005) undertook genotyping of WSSV samples from Vietnam, targeting ORF 94. Samples included PL, shrimps and crabs in outbreak and non-outbreak ponds during December 2001 to June 2002. In that study, 7 and 9 repeats accounted for $94 \%$ of samples in outbreak ponds. In infected PL and broodstock, the 7 repeat genotype was observed in only $15 \%$ of samples, with 4 to 6 repeats being most common (69\%).

In the present study, the lowest number of RUs obtained in ORF 94 was 2 (Table 3) in contrast with the earlier reports of 4 RU in Vietnam (Hoa et al. 2005) and 6 RU in Thailand and India (Wongteerasupaya et al. 2003, Dieu et al. 2004, Musthaq et al. 2006). These results suggest that, although similarities are evident between WSSV strains studied from Thailand and Vietnam, the RU types 2 and 3 observed in this study represent new Indian variants of WSSV. As with previous studies in Thailand (Wongteerasupaya et al. 2003) and India (Musthaq et al. 2006), 2 PCR amplicons of different size from ORF 94 (Fig. 2) was observed. This was interpreted as a dual infection by 2 different WSSV genotypes.

Previously, Wongteerasupaya et al. (2003) observed that 6 to 9 RUs accounted for $70 \%$ of samples from outbreak ponds in Thailand. In Vietnam during 2001 to 2002, RU of 7 and 9 were dominant and the 8 repeat genotype was absent in outbreak ponds (Hoa et al. 2005). In India during 2002 to 2004, genotypes with 6, 7 or 8 RUs accounted for $57 \%$ of samples from outbreak ponds (Musthaq et al. 2006). Unfortunately WSSV samples from non-outbreak ponds were not examined. In this study, we found that genotypes with less than 8 repeats were dominant in outbreak ponds. This is in contrast to non-outbreak ponds where genotypes with >9 RUs were dominant. In general it appears that WSSV genotypes with less than 9 repeats in ORF 94 are dominant in outbreak ponds.

Crabs samples from non-outbreak ponds were all negative for WSSV and even in outbreak ponds could only be detected by 2nd step PCR, suggesting a lower viral load in crabs. A similar situation was observed with wild shrimp where one sample from an outbreak pond and another from a non-outbreak pond were WSSV PCR 2nd step positive. These samples failed to produce any product in the ORF 94 genotyping PCR. This was probably due to the low level of virus present in these samples. These findings are consistent with Hoa et al. (2005) who also reported apparently lower levels of WSSV infection in crabs in outbreak ponds and failure of the ORF 94 genotyping PCR to produce a product.

Comparative analysis of the $54 \mathrm{bp}$ variable sequence in genomes of WSSV-TH, WSSV-TW and WSSV-CN revealed an alternate $\mathrm{T}$ or $\mathrm{G}$ at the 48 th base. Similar base variation was reported for Vietnam (WSSV-VN, Dieu et al. 2004) and Indian (WSSV-IN, Musthaq et al. 2006) isolates. Wongteerasupaya et al. (2003) reported SNP at the 36th position in their study with WSSV isolates from Thailand. All samples tested in our study showed a SNP at 48th base, except for one sample where SNPs were observed at the 7 th and 44th position. The difference in the position of the SNP at the 36th and 48th positions is a result of the way in which the position of the repeats is calculated. In the case of WSSV-TH (Genbank AF369029), if the repeat starts from position 142744 starting with CGC and ending with TAC at position 142797, the SNP falls at 48th position. In contrast if the repeat begins at position 142756 
starting with GCC and ending with CGT at position 142809 of the genome, the SNP falls at 36th position. This difference is due to the partial repeat of $12 \mathrm{bp}$ at the end of the $54 \mathrm{bp}$ repeat (Fig. 5).

As with the $54 \mathrm{bp}$ tandem repeat in ORF 94, there are also variations in the number of $69 \mathrm{bp}$ minisatellite repeats in ORF 125 (Dieu et al. 2004). Those authors reported 5 RU genotypes. In this study, we found the number of $69 \mathrm{bp}$ repeats varied between 2 and 14 (Table 3), which further demonstrates the variation observed in Indian WSSV genotypes. Also, we observed SNPs to occur at the first and the last repeat unit, which is in contrast with that reported in Vietnam (Dieu et al. 2004) and Thailand (Marks et al. 2004) wherein the SNPs were found in the third to the penultimate repeat at positions $8,18,25,66$ and 69. Although SNPs were not determined for the compound repeat, DNA sequencing revealed a number of variable 45 bp repeats interspersed by a constant 57 bp repeat (Fig. 4). This is in agreement with the previous observation of Shekar et al. (2005), but is in contrast with those reported by Marks et al. (2004) and Dieu et al. (2004) who found RUs of 102 and $45 \mathrm{bp}$.
The largest variation in tandem repeats was found in ORF 94 where 13 different repeat patterns were observed. ORF 125 displayed 11 different repeat patterns and ORF 75 showed the least variation with 6 different repeat patterns. Dieu et al. (2004) found the largest genomic variation to occur in the unidirectional tandem repeats located in ORF 94. This suggests that among the 3 variable minisatellites, ORF 94 is best suited for genotyping WSSV based on single variable loci. Furthermore, we observed that even though WSSV strains may have the same repeat pattern for a particular minisatellite the other 2 minisatellites need not always have the same pattern. This variation can also be observed in the 3 complete DNA sequences of WSSV in Genbank; although WSSV-TH and WSSVTW have 6 repeats in ORF 94, the number of repeats in the other 2 minisatellites (ORF 125 and 75) is different. Our observations suggest it may be useful to consider all the 3 minisatellite loci, rather than a single locus for epidemiological studies.

In all of our samples, $6.6 \%, 38.7 \%$ and $52.8 \%$ showed no amplification for the ORFs 125, 94 and 75, respectively. Most of the 1st step WSSV PCR positive samples showed amplification in the genotyping PCRs.

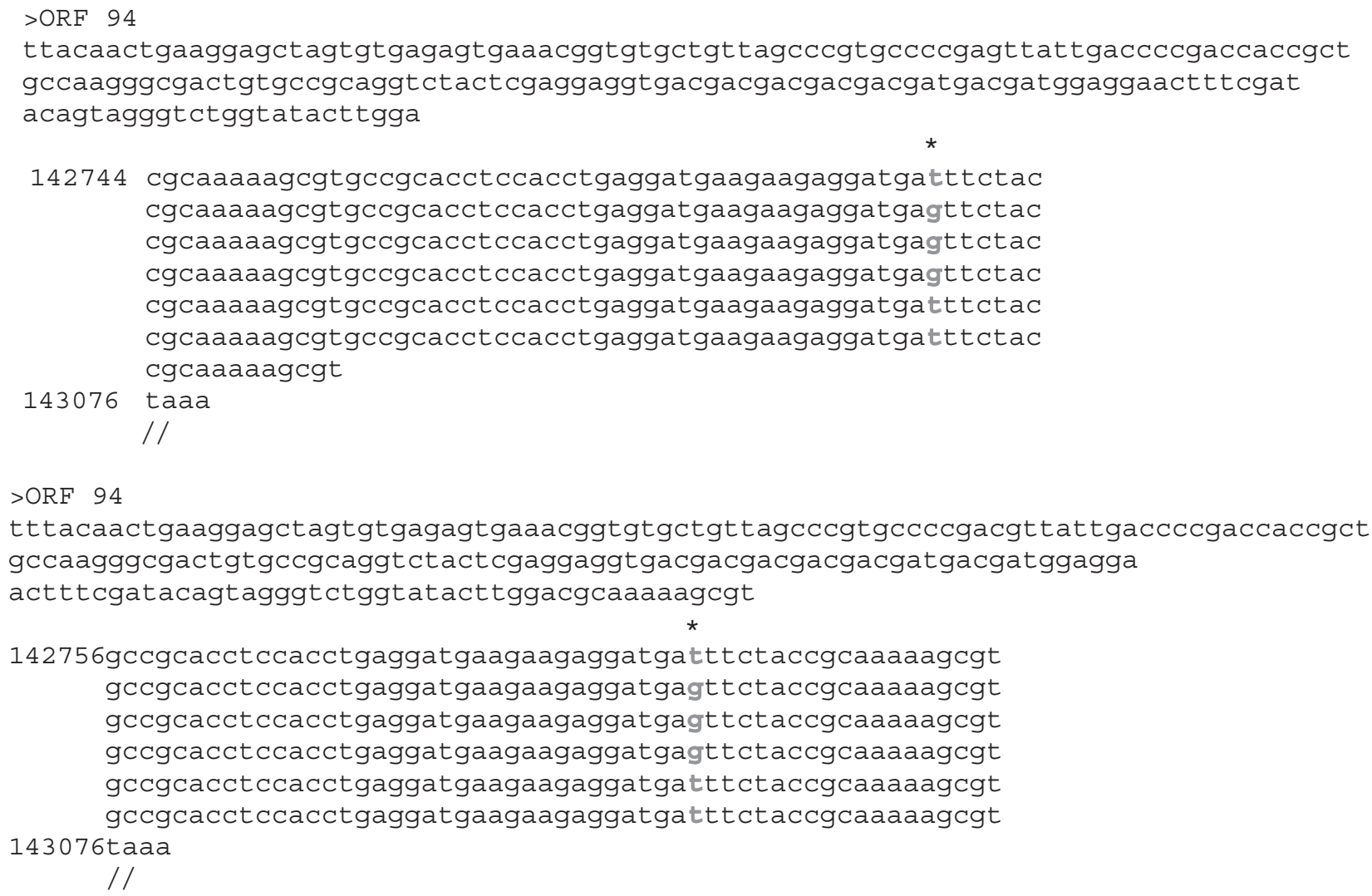

Fig. 5. ORF 94 of WSSV-TH showing 2 different 54 bp repeat pattern sequences. ORF 94 repeat units with SNPs at 48 th and 36 th position are indicated by * and grey letter 
In samples positive by 1 -step PCR, only $13.3 \%, 11.6 \%$ and $31.6 \%$ of the samples could not produce any amplicon for ORF 94, ORF125 and ORF 75 genotyping PCR, respectively. The failure in PCR could be due to low levels of WSSV which could only be amplified by a nested PCR. The variation in non-amplification among the 3 genotyping PCRs may also reflect sequence variation at the associated primer binding sites. Hossain et al. (2001) also attributed amplification failure to variation in the primer binding site or to low levels of target DNA. The lower rate of failure in the case of ORF 125 PCR suggests the primer binding region flanking the $\mathrm{RU}$ is more stable and less prone to genetic variation. The ratio of host DNA and viral DNA also could have affected the efficiency of genotyping PCR. The ladder effect seen as bands smaller than the expected product has also been recorded by Hoa et al. (2005), who summarized this to be an amplification artifact since the ladder effect disappeared on dilution of the sample while the expected product remained.

An interesting observation in this study is the similarity observed in the tandem repeats in ORF 125 among WSSV infected carrier animals (wild shrimp Acetes sp., crabs) and cultured shrimp in a geographical area suggesting infection by same strain of the virus. This is not surprising as the role of carrier animals in spread of WSSV has always been suspected (Lo et al. 1996, Hossain et al. 2001). Our observation is in contrast with that made by Waikhom et al. (2006), who observed differences and attributed the difference in tandem repeat number to be a result of host selection rather than geographical isolation. Further, the repeat units in shrimp from 3 locations, i.e. Palakollu, Kakinada and Bhimavaram (Table 5), showed significant differences, particularly in the 54 bp RU, while within a location, they were almost identical. This indicates prevalence of different viral strains in each location. Since WSSV negative larvae were stocked in the ponds the source of infection could be carrier animals like Acetes sp. and crabs, which were found positive for WSSV and presented similarity in their repeat units with that of WSSV infected shrimp. These results have a significant bearing on management of WSSV infection in shrimp aquaculture systems and the necessity to keep natural carriers away as an effective measure to prevent infection by this virus. The low level of infection in crabs suggests that they may be acting as reservoirs in transmission of WSSV in the ponds.

Our analysis of the 3 minisatellite regions shows that some Indian strains of WSSV are distinct from strains found in other geographical regions such as Thailand and Vietnam. While the variations in minisatellites could be useful in global epidemiological studies, the SNPs observed within repeats can be useful in track- ing the movement of virus within more localized geographical locations.

Variable number tandem repeats are not only useful in epidemiological studies, but also in studying the host adaptation and virulence mechanism of an organism. Studies have shown that variation in repeats within a protein-coding ORF can act as 'molecular switches' bringing about phenotypic variation, which in turn will help the organism to survive changing environmental conditions and, thus, help the pathogen to adapt to its host as the infection progresses. Considering that the WSSV in our study was mostly from diseased or outbreak farms, it remains to be seen whether the repeat variability observed within the 3 ORFs has any implication in the virulence mechanism of this virus.

Acknowledgements. This work was supported by grants from the Department of Biotechnology, Government of India under 'Programme Support in Fisheries Biotechnology'. The first author is thankful to the Australian Centre for International Agricultural Research (ACIAR) for award of a research fellowship.

\section{LITERATURE CITED}

Benson G (1999) Tandem repeats finder: a program to analyse DNA sequences. Nucleic Acids Res 27:573-580

Dieu BTM, Marks H, Siebenga JJ, Goldbach RW, Zuidema D, Duong TP, Vlak JM (2004) Molecular epidemiology of white spot syndrome virus within Vietnam. J Gen Virol 85:3607-3618

Durand S, Lightner DV, Redman RM, Bonami JR (1997) Ultrastructure and morphogenesis of white spot syndrome baculovirus (WSSV). Dis Aquat Org 29:205-211

Flegel TW (1997) Major viral diseases of the black tiger prawn (Penaeus monodon) in Thailand. World J Microbiol Biotechnol 13:433-442

Hoa TT, Hodgson RA, Oanh DT, Phuong NT, Preston NJ, Walker PJ (2005) Genotypic variations in tandem repeat DNA segments between ribonucleotide reductase subunit genes of white spot syndrome virus (WSSV) isolates from Vietnam. In: Diseases in Asian aquaculture V. Fish Health Sect, Asian Fish Soc, Manila, p 339-351

Hossain MS, Chakraborty A, Joseph B, Otta SK, Karunasagar I, Karunasagar I (2001) Detection of new hosts for white spot syndrome virus of shrimp using nested polymerase chain reaction. Aquaculture 198:1-11

Karunasagar I, Otta SK, Karunasagar I (1997) Histopathological and bacteriological study of white spot syndrome of Penaeus monodon along the west coast of India. Aquaculture 153:9-13

Lo CF, Ho CH, Peng SE, Chen CH and others (1996) White spot syndrome baculovirus (WSBV) detected in cultured and captured shrimp, crab and other arthropods. Dis Aquat Org 27:215-225

Lo CF, Hsu HC, Tsai MF, Ho CH, Peng SE, Kou GH, Lightner DV (1999) Specific genomic DNA fragment analysis of different geographical clinical samples of shrimp white spot syndrome virus. Dis Aquat Org 35:175-185

Marks H, Goldbach RW, Vlak JM, van Hulten MCW (2004) Genetic variation among isolates of white spot syndrome virus. Arch Virol 149:673-697 
Marks H, van Duijse JJ, Zuidema D, van Hulten MC, Vlak JM (2005) Fitness and virulence of an ancestral white spot syndrome virus isolate from shrimp. Virus Res 110:9-20

Mayo MA (2002) A summary of taxonomic changes recently approved by ICTV. Arch Virol 147:1655-1663

Musthaq SS, Sudhakaran R, Ahmed IVP, Balasubramanian G, Hameed SAS (2006) Variability in the tandem repetitive DNA sequence of white spot syndrome virus (WSSV) genome and stability of VP28 gene to detect different isolates of WSSV from India. Aquaculture 256:34-41

Nadala ECB Jr, Loh PC (1998) A comparative study of three different isolates of white spot virus. Dis Aquat Org 33: 231-234

Nadala ECB Jr, Tapay LM, Loh PC (1998) Characterization of a non-occluded baculovirus-like agent pathogenic to penaeid shrimp. Dis Aquat Org 33:221-229

Shekar M, Karunasagar I, Karunasagar I (2005) A computerbased identification of variable number tandem repeats in white spot syndrome virus genomes. Curr Sci 89:882-887

Tsai MF, Lo CF, van Hulten MC, Tzeng HF and others (2000) Transcriptional analysis of the ribonucleotide reductase genes of shrimp white spot syndrome virus. Virology 277:92-99

van Hulten MCW, Tsai MF, Schipper C, Lo AF, Kou GH, Vlak JM (2000) Analysis of a genomic segment of white spot syndrome virus of shrimp containing ribonucleotide reductase genes and repeat regions. J Gen Virol 81: 307-316

van Hulten MCW, Witteveldt J, Peters S, Kloosterboer N and others (2001) The white spot syndrome virus DNA genome sequence. Virology 286:7-22

Vlak JM, Bonami JR, Flegel TW, Kou GH and others (2004) Nimaviridae. In: Fauquet CM, Mayo MA, Maniloff $\mathrm{J}$,

Editorial responsibility: Timothy Flegel,

Bangkok, Thailand
Desselberger U, Ball LA (eds) Eighth report of the International Committee on Taxonomy of Viruses. Elsevier, Amsterdam, p 187-192

Waikhom G, John KR, George MR, Jeyaseelan MJP (2006) Differential host passaging alters pathogenicity and induces genomic variation in white spot syndrome virus. Aquaculture 261:54-63

> Wang Q, Nunan LM, Lightner DV (2000a) Identification of genomic variations among geographic isolates of white spot syndrome virus using restriction analysis and southern blot hybridization. Dis Aquat Org 43:175-181

Wang Q, Poulos BT, Lightner DV (2000b) Protein analysis of geographic isolates of shrimp white spot syndrome virus. Arch Virol 145:263-274

Wang YC, Lo CF, Chang PS, Kou GH (1998) Experimental infection of white spot baculovirus in some cultured and wild decapods in Taiwan. Aquaculture 164:221-231

Wongteerasupaya C, Vickers JE, Sriurairatana S, Nash GL and others (1995) A non-occluded, systemic baculovirus that occurs in cells of ectodermal and mesodermal origin and causes high mortality in the black tiger prawn Penaeus monodon. Dis Aquat Org 21:69-77

> Wongteerasupaya C, Pungchai P, Withyachumnarnkul B, Boomsaeng V, Panyim S, Flegel TW, Walker PJ (2003) High variation in repetitive DNA fragment length for white spot syndrome virus (WSSV) isolates in Thailand. Dis Aquat Org 54:253-257

Xie X, Li H, Xu L, Yang F (2005) A simple and efficient method for purification of intact white spot syndrome virus (WSSV) viral particles. Virus Res 108:63-67

Yang F, He J, Lin XH, Li Q, Pan D, Zhang XB, Xu X (2001) Complete genome sequence of the shrimp white spot bacilliform virus. J Virol 75:11811-11820

Submitted: March 6, 2007; Accepted: October 23, 2007

Proofs received from author(s): December 7, 2007 